\title{
Stanisław Salmonowicz
}

\section{Oratio pro domo sua, czyli kilka uwag o nauce historii prawa w Polsce}

\author{
"Sine historia caeca est jurisprudentia” \\ Francis Baudouin, XVI wiek
}

Keywords: history of law, Polish partitions

\section{Summary}

The text is addressed at first to young historians and historians of law. It stresses the peculiar importance of the science of the history of law and legal education in Polish historical science, especially in the period between 1850-1914. The science of history of law has been strongly connected with historical science, and law was a phenomenon shaped par excellence by history. In 19th century Poland, when the partitioners were replacing Polish law and Polish institutions by their own legal systems, Polish historians of law had to struggle to preserve national legal traditions. That is why the strong position of F. K. von Savigny's historical school of law is presented in Polish Romanticism. The article describes the achievements of Polish historians of law in the field of national history science. It points out that many of the historians in this period were lawyers by education (Szymon Askenazy, Tadeusz Korzon, Władysław Smoleński, Marceli Handelsman, Władysław Konopczyński). Nowadays the role of the science of history of law is underestimated, although the cooperation of historians of law with the representatives of other historical disciplines is fruitful.

Chciałbym zwięźle przedstawić pogląd mój o szczególnej roli nauki historii prawa w dziejach polskiej kultury i w dziejach polskiej historiografii dla epoki okresu porozbiorowego, a zwłaszcza w dobie gdzieś od połowy XIX w., aż po rok 1914. Chciałbym więc krótko ukazać jakie były tej roli przyczyny, skutki i szczególne okoliczności, których już zabraknie - etapami - w dobie II Rzeczypospo- 
litej i w okresie po drugiej wojnie światowej, choć nadal, w moim przekonaniu, nauka historii prawa pozostała znaczącym elementem nauk historycznych, nie rezygnując przecież z swej roli w modelu studiów prawniczych.

Rozpoczynając swe rozważania przypomnę inny, znamienny cytat znamiennego autora. To Michał Bobrzyński, historyk prawa par excellence i jeden z najgłośniejszych polskich historyków, pisał u progu swej kariery naukowej: „Historia prawa jest to najlepsza cząstka $z$ ogólnej historii narodu, cząstka może najwięcej pouczająca”. Jeżeli przyjąć za istotne określenie, iż jest to „cząstka pouczająca", to możemy widzieć w tym programowym sformułowaniu zapowiedź poglądu, który Bobrzyński głosił całe życie: o roli państwa, roli „siły” jaką naród musi dysponować, a którą to siłą jest odpowiednio dobrana forma ustroju².

Przez wiele wieków w Europie nauka historii i prawa ściśle się ze sobą wiązały, nade wszystko dlatego, że prawo średniowiecza i czasów nowożytnych, miało swoje, z reguły bardzo skomplikowane, źródła prawa i doktryny prawnej, które początkami sięgały epoki starożytnej, grecko-rzymskiej, jak i roli prawa rzymskiego. Późniejszy rozwój prawa, w sporej mierze prawa zwyczajowego, bądź kontynuującego przez wieki trwałość gros instytucji prawnych, powodowały, iż znajomość źródeł prawa, ich interpretacja, geneza, wymagały wiedzy historycznej. W istocie - czas długi - uczeni prawnicy traktowali naukę historii jako swego rodzaju naukę pomocniczą, niezbędną w wiedzy każdego prawnika. Wynikało to z faktu, iż zarówno prawo publiczne, jak i prawo sądowe, przez wieki miało charakter zjawisk głęboko w przeszłości umocowanych i dotyczyło to nie tylko szczególnie reprezentacyjnej z tego punktu widzenia ewolucji prawa angielskiego, ale i praw europejskich na całym niemal kontynencie. „W niemieckim nauczaniu uniwersyteckim rozwinęła się w XVIII w. historia ustroju Rzeszy Niemieckiej (Reichshistorie), która stanowiła swego rodzaju poprzedniczkę późniejszej historii prawa sensu stricto, a głównie służyła przedstawicielom nauki prawa publicznego jako materiał informacyjny"3. Podobne tradycje naukowe szeroko reprezentowała nauka francuska, włoska, czy polska w XVI-XVII w. Rozkwit przecież europejskiego oświecenia, rola doktryny prawa natury, pozwa-

1 M. Bobrzyński, O dawnym prawie polskim, jego nauce umiejętnym badaniu, tekst z 1874, wg przedruku w: idem, Szkice i studia historyczne, t. II, Kraków 1922, s. 309.

2 Por. pogląd Bobrzyńskiego: „Każda forma rządu jest dobrą, która w danych warunkach zapewnia narodowi i państwu pieczę jego interesów, silny rząd i ogólny rozwój” - wg W. Kaute, Synteza dziejów Polski Michała Bobrzyńskiego, Katowice 1993, s. 64.

3 S. Salmonowicz, Gotfryd Lengnich. Szkic do portretu uczonego, [w:] idem, Od Prus Książęcych do Królestwa Pruskiego. Studia z dziejów prusko-pomorskich, Olsztyn 1992, s. 75. Warto pamiętać, iż znawca prawa polskiego i historii ustroju Rzeczypospolitej, ale nade wszystko prawnik, jakim był G. Lengnich (1689-1774), był wychowankiem niemieckiej szkoły prawa publicznego w Halle, której twórca, J. P. Ludevig (1668-1743), wielokrotnie głosił, iż tylko prawnik może z powodzeniem uprawiać historię. 
lającej na oderwanie się od litery prawa obowiązującego i otwierającego drogę do wielkiej reformy prawa $\mathrm{w}$ duchu nade wszystko koncepcji kodyfikacyjnej, racjonalnej, w pewnym sensie kosmopolitycznej, powodowały, iż pod koniec XVII w. panował generalnie kult prawa stanowionego, odrzucającego wszelkie „feudalne", historyczne „nawarstwienia” w rozwoju prawa na rzecz idei kodyfikacji prawa, mającej nieraz z dużą przesadą, budować nowy, racjonalny gmach prawa ex nihilo, formalnie odrzucając zaistniały stan rzeczy. W obliczu Rewolucji Francuskiej narodziła się przecież swego rodzaju reakcja antyoświeceniowa w dziedzinie teorii prawa, która, broniąc narodowych korzeni prawa, w sposób zasadniczy określiła rolę nowej dyscypliny - historii prawa - w naukach prawnych, której najwybitniejszym przedstawicielem był Fryderyk K. von Savigny (1779-1861).

Niemiecka Szkoła Historyczna, nie bez także wyraźnych akcentów pangermańskiej koncepcji historii, kładła więc nacisk na szukanie w prawie „ducha narodu" (Volksgeist), odrzucała tworzenie prawa oderwanego od jego historycznych, narodowych korzeni, widziała naukę prawa nade wszystko jako eine geschichtliche Wissenschaft ${ }^{4}$, bowiem prawo wywodzi się, podobnie jak język czy obyczaje, z ducha danego narodu w sposób „organiczny”.

Dla von Savignego prawo było historycznym produktem ducha danego narodu, jego koncepcje stawiały badania historycznoprawne na piedestale jako zasadniczy element wszelkiej naukowej działalności w zakresie prawa. Nie było więc rzeczą przypadku, iż poglądy szkoły historycznej niemieckiej w prawoznawstwie odegrały zasadniczą rolę w Polsce i w niektórych krajach słowiańskich. Upadek państwa polskiego stworzył bowiem zupełnie nową sytuację: przez cały wiek XIX aż po rok 1918 o tworzeniu nowego prawa polskiego, pomijając kilka krótkich epizodów (Księstwo Warszawskie, Królestwo Polskie), w istocie nie było mowy. Stąd konieczność traktowania historii narodowej, historii ustroju i prawa polskiego z wielu nowych przyczyn, które równocześnie, mniej lub bardziej współgrały z niezwykle wpływową dla całej europy środkowo-wschodniej koncepcją von Savignego. Po okresie napoleońskim rozkwit niemieckich uniwersytetów był faktem istotnym z wielu względów; polscy adepci nauki, zwłaszcza w 1. połowie XIX w., studiowali nade wszystko na uniwersytetach niemieckich i austriackich. W miarę upływu czasu, zwłaszcza po roku 1831, Polacy mieli w kraju głównie do czynienia z prawem obowiązującym: pruskim, niemieckim, austriackim, czy rosyjskim. Stąd obrona polskiej tradycji ustrojowej i tradycji prawa epoki Rzeczypospolitej polsko-litewskiej stała się - można tak powiedzieć - priorytetowym zadaniem polskiej nauki prawa, zwłaszcza w 2. połowie wie-

4 J. Schröder, Biogram Savignego, [w:] G. Kleinheyer, J. Schröder, Deutsche Juristen aus fünf Jahrhunderten, 3. Aufl., Heidelberg 1989, s. 240; ibidem, s. 244-246 bibliografia przedmiotu. 
ku XIX. Jeżeli instytucje, czy możliwości cenzuralne dla zajmowania się „,czystą" historią narodową napotykały w różnych sytuacjach na ogromne trudności (w każdym razie poza Galicją epoki autonomii), to katedry uniwersyteckie, czy inne działania w zakresie badania prawa polskiego, miały przez czas dłuższy także pewne uzasadnienie praktyczne (w każdym razie w zaborze rosyjskim i dla prawa sądowego). Stąd, bez względu na fakt ogromnych trudności wynikających z warunków rozwoju nauki polskiej (zwłaszcza w okresie od 1832 do 1869), szukano szczególnie, nie tylko w Galicji, ale i w Królestwie Polskim (Kongresówce), możliwości naukowego zajmowania się właśnie polską tradycją prawną w różnych aspektach, także bardzo istotnych dla ogólnego obrazu historii narodowej. W rezultacie, także $\mathrm{z}$ uwagi na zasadniczy dylemat naukowy - problem przyczyn upadku państwa polskiego - w XIX w. nie tylko prawnicy ale i historycy, poczynając od wielkiej postaci historyka Joachima Lelewela, „...uczynią dzieje prawa politycznego osią historii narodu"'.

Tego typu postawa zwrócenia się ku przeszłości, nb. zgodna z ogólnymi tendencjami romantyzmu europejskiego po roku 1815, co niekoniecznie musiało wiązać się z konserwatywnymi, czy wręcz reakcyjnymi, poglądami polityczny$\mathrm{mi}^{6}$, była u wielu prawników polskich tej epoki pojmowana jako obowiązek wobec sytuacji narodu, obrona ważnych elementów kultury narodowej, a także w ten czy inny sposób nieraz pośrednio czy bezpośrednio - pojmowana jako negacja szerzonej przez rozbiorców wizji upadku Rzeczypospolitej polsko-litewskiej. Podejmując zaś badania $\mathrm{z}$ historii prawa stosunków społeczno-gospodar-

5 J. Siemieński, Historia tak zwanej historii ustroju Polski. Zarys. Część I, „Przegląd Historyczny” 1928, R. 28, s. 395. Dalszego ciągu tej pracy autor nie opracował. Generalnie por. zwięzły zarys rozwoju nauki historii prawa w Polsce: A. Vetulani, Dzieje historii prawa w Polsce, Kraków 1948. Brakuje nam dziś obszerniejszego ujęcia tej tematyki i doprowadzenia chronologii rozważań przynajmniej do roku 1989. O narodzinach nauki historii prawa w Polsce por. moje uwagi, La littérature juridique du XVIII e siècle polonais et les débuts de la Science de l'Histoire du Droit, „Revue Historique de Droit français et étranger" 1964, R. 42, 1, s. 84-95. Do uwag J. Siemieńskiego można dodać, iż historycy prawa sądowego, szeroko traktując swe badania, ogarniali z reguły całokształt ustroju społeczno-gospodarczego, zwłaszcza epoki średniowiecza.

6 W Polsce romantyzm bowiem od strony ideologiczno-politycznej różnił się znacznie od panującego prądu konserwatywnego w krajach niemieckich, a najważniejsza szkoła w historiografii polskiej dla pierwszej połowy XIX w. - szkoła Lelewelowska była politycznie wyrazem republikańskich, demokratycznych i antyfeudalnych poglądów.

7 Pamiętać trzeba zawsze o tym, iż zasadniczy spór historiograficzny XIX w. między Lelewelowską szkołą romantyczną a tzw. historyczną szkołą krakowską 2. połowy XIX w., toczony z udziałem wielu uczonych przynajmniej intensywnie do roku 1914, był sporem o przyczyny strukturalne i polityczne upadku Rzeczypospolitej szlacheckiej, w którym to sporze kwestie ustrojowe grały siłą rzeczy rolę zasadniczą i stąd poglądy historyków prawa, czy historyków o dużej wiedzy ustrojowej, odgrywały tu wielką rolę. Tu odwołajmy się, poza publikacjami M. Bobrzyńskiego, do takich istotnych tekstów jak O. Balzera, Z zagadnień ustrojowych Polski, Lwów 1915 (wznowienie w 1985), 
czych, historycy prawa mieli, raz jeszcze to podkreślam, nieraz łatwiejszą sytuację, niż autorzy podejmujący w XIX w. problemy historii politycznej sensu stricto, stosunków Rzeczypospolitej z sąsiadami - państwami rozbiorczymi itd. Można więc powiedzieć, iż w ten sposób wielokrotnie polska historiografia prawa rozwijała badania, które nieraz moglibyśmy określić jako badania „procesów długiego trwania”, przy pewnym negliżowaniu „historii zdarzeniowej”. To właśnie wielkie procesy rozwojowe historii narodowej były głównym tematem badań polskich historyków prawa, zwłaszcza w epoce przełomu XIX i XX w., i wysuwała się ona w ten sposób wielokrotnie na czoło ówczesnych polskich nauk historycznych. Nawet niekiedy zdołano prowadzić dość swobodne badania nad dziejami prawa polskiego na fakultetach formalnie uniwersytetów rosyjskich. Natomiast prowadzenie dydaktyki z zakresu historii politycznej Polski było o wiele trudniejsze i w okresie po Powstaniu Styczniowym mogło mieć miejsce jedynie w formalnych strukturach uniwersytetów galicyjskich doby autonomii: w Krakowie i we Lwowie. Nikt wprawdzie do tej pory nie przeprowadził szczegółowych badań nad rolą cenzury rosyjskiej w okresie 1864-1914. Można jednak ogólnie stwierdzić, iż była ona mniej dokuczliwa jeżeli chodziło o problemy dalekie od współczesności i od spraw rosyjsko-polskich.

Nie jest oczywiście możliwe ukazanie w zwięzły sposób całego bogactwa historiografii prawa w XIX w. aż po rok 1914. Nie jest więc moim celem omawianie badań poszczególnych autorów, a jedynie zaakcentowanie najważniejszych faktów ogólnych ${ }^{8}$. Zacznijmy od stwierdzenia, iż podwaliny pod rozwój historiografii ustroju i prawa dawniej Rzeczypospolitej kładli początkowo prawnicy oświeceni epoki drugiej połowy XVIII w. idący za dziełami Lengnicha, czy ustaleniami Naruszewicza. Za nimi szli pierwsi - moim zdaniem - historycy prawa, dla których prawo obowiązujące nie było już głównym przedmiotem badań, czyli stawali się historykami prawa, a nie prawnikami badającymi fakty historyczne dla potrzeb prawa obowiązującego. Mam tu na myśli Krystiana B. Steinera, Tadeusza Czackiego i kontynuującego ich dzieła badacza początków XIX w.

publikacji Stanisława Kutrzeby, jak i wielkiego dzieła Władysława Konopczyńskiego, Liberum veto. Studium porównawczo-historyczne, Kraków 1918 (przekł. francuski; oraz II wydanie Kraków 2002). Badania historyczne były więc traktowane wielokrotnie jako oręż w walce o byt narodowy, por. ogólnie: J. Dybiec, Nie tylko szabla - nauka i kultura polska w walce o utrzymanie tożsamości narodowej 1795-1918, Kraków 2004.

8 Faktem jest, iż niektórzy historycy prawa wieku XIX nie posiadają nie tylko żadnego szerszego opracowania monograficznego, ale i niekiedy brak nam do dziś nawet ich biogramów w PSB. O najważniejszych, którzy odegrali rolę także dla nauki światowej, por. moje uwagi: Wkład polskiej nauki prawa do światowego dziedzictwa, [w:] red. I. Staśkiewicz-Jasiukowa, Wkład osiagnięć polskiej nauki i techniki do dziedzictwa światowego, Kraków - Warszawa 2009, s. 312-315, O rozkwicie polskiej nauki historii prawa na przełomie XIX/XX w. 
Jana Wincentego Bandtkie ${ }^{9}$. Za nimi, ale nieraz w nowych już koncepcjach, które niosła romantyczna historiografia, szedł historyk o ogromnych zasługach, także dla historii prawa, jakim był znakomity badacz tej epoki Joachim Lelewel $(1786-1861)^{10}$.

Romantyczną historię prawa reprezentował nade wszystko Wacław Aleksander Maciejowski (1792-1883), uczeń Niemieckiej Szkoły Historycznej Karla von Savignego, ale i Karola F. Eichhorna, prekursora niemieckiej szkoły historycznej w prawoznawstwie ${ }^{11}$. Maciejowski, choć politycznie przechodził z czasem na pozycje lojalizmu wobec władzy carskiej, był także w wielu kwestiach bliski romantycznej szkole Lelewela, a wychodząc z założeń ogólnych von Savignego przekształcał przecież historycznie i politycznie owe założenia w służbie sprawy narodów słowiańskich i ich niezależnej, jego zdaniem, roli wobec narodów germańskich. Stąd szukał owego „ducha ludowego” (Volksgeistu von Savignego) w dziejach prawa narodów słowiańskich. W tej mierze miał przecież ważnego naukowego prekursora w Polsce. Był nim Ignacy. B. Rakowiecki (1783-1839) autor publikacji pt. „Prawda Ruska czyli prawa Wielkiego Księcia Jarosława Władymirowicza" ogłoszonej w latach 1820-1822, którego należy uznać za twórcę metody historyczno-porównawczej w badaniach nad historią prawa narodów słowiańskich ${ }^{12}$. Maciejowski doktorat $\mathrm{z}$ prawa uzyskał w Getyndze, ale teorię historycznoprawną nauki niemieckiej wykorzystał dla obrony wartości rodzimych praw narodów słowiańskich i jest $\mathrm{w}$ istocie twórcą doktryny słowianofilstwa w naukach prawnych, doktryny, która zapanowała na czas długi w całej Europie środkowo-wschodniej, a w nauce rosyjskiej panowała niemal niepodzielnie po rok 1917.

Wacław A. Maciejowski był nade wszystko autorem głośnego wielotomowego dzieła pt. „Historia prawodawstw słowiańskich” (wyd. I: 1832-1835, wyd. II

9 Por. ogólnie S. Salmonowicz, Krystian Bogumił Steiner (1745-1814). Toruński prawnik i historyk. Studium $z$ dziejów nauki prawa doby Oświecenia w Polsce, Toruń 1962.

10 Por. J. Adamus, Joachim Lelewel jako historyk prawa, „Czasopismo Prawno-Historyczne” (dalej: CPH) 1962, T. 14, 1, s. 9-34; por. ogólnie: G. Bałtruszajtys, Zarys dziejów Wydziału Prawa i Administracji Uniwersytetu Warszawskiego. 1808-2008, Warszawa 2008, tamże dalsza literatura przedmiotu.

11 Por. wielka monografia J. Bardach, Wacław Aleksander Maciejowski i jego współcześni, Wrocław 1971 i W. Sobociński, Wacław Aleksander Maciejowski w nauce polskiej XIX w. (W związku z książką Juliusza Bardacha), CPH, T. 24, 1972, 2, s. 185-213.

12 A. Vetulani, op. cit., s. 12, pisząc o roli Rakowieckiego stwierdził: „...nauka polska znalazła zupełnie samodzielnie podstawę do wyzwolenia się spod hipnozy wyższości prawa germańskiego nad prawem Słowian oraz spod działania teorii o normańskim pochodzeniu prawa polskiego i prawa innych narodów słowiańskich"; por. ogólnie: istotna rozprawa T. Taranowskiego, $Z$ powodu setnej rocznicy dzieła J. B. Rakowieckiego jako pierwszej pracy na polu historii porównawczej prawodawstw słowiańskich (1829-1920), „Czasopismo Prawno-Ekonomiczne” 1921, t. XIX, z. 5-6; por. ogólnie także: J. Bardach, Historia praw słowiańskich. Przedmiot i metody badawcze, [w:] idem, Themis a Clio, czyli prawo a historia, Warszawa 2001, s. 147-182. 
rozszerzone: w latach 1835-1839, szereg przekładów, w tym wydanie niemieckie w latach 1835-1839, wznowione: 1978), w którym to dziele, pełnym erudycji, ale dziś mocno anachronicznym, co wynikało z ówczesnego stanu badań źródeł średniowiecznych, formułował bardzo romantyczną i quasi-nacjonalistyczną teorię o wyższości pierwotnego prawa prasłowiańskiego nad prawami ludów germańskich, przez co odrzucał poglądy historyków niemieckich, którzy już w tej epoce odmawiali narodom słowiańskim, w tym i Polakom „zdolności państwowotwórczych". Stąd z punktu widzenia historii nauki wystąpienie Maciejowskiego miało znaczne i trwałe konsekwencje, a jego dorobek naukowy „...choć w znacznej mierze już dziś przestarzały, stanowi trwałą pozycję w historiografii polskiej i słowiańskiej"13.

Po wystąpieniu Maciejowskiego polska nauka historii prawa w pewnej mierze na długo będzie rezygnować z prób wielkiej syntezy, podejmować będzie, na wzór najlepszych krytycznych metod niemieckich, prace monograficzne i wydania źródeł historycznych. Naukowe metody, także w zakresie wydawnictw źródłowych, wprowadzał w Krakowie Antoni Zygmunt Helcel (1808-1870), wydawca pierwszych tomów „Starodawnego prawa polskiego pomników” ${ }^{14}$. Helcel, zbliżony do powstającej po roku 1864 tzw. krakowskiej szkoły historycznej, to było zdecydowane odejście od romantycznej szkoły Joachima Lelewela. Helcel preferował studia źródłowe ograniczone, ostrożne, stworzył podwaliny pod krytyczną szkołę studiów prawa polskiego, z której miał zasłynąć Kraków. Kontynuację jego działań na polu źródłoznawczym stanowiły dokonania Bolesława Ulanowskiego (1860-1919), Franciszka Piekosińskiego (1844-1906), Michała Bobrzyńskiego (1849-1935), czy Stanisława Kutrzeby (1876-1946) ${ }^{15}$. We Lwowie wielką działalność edytorską prowadził nade wszystko wybitny historyk dziejów Kościoła katolickiego, Władysław Abraham (1860-1941). W Warszawie uczeń i Maciejowskiego, i filozofa Hegla, Romuald Hube (1803-1890), wybitny prawnik karnista, ale i gorliwy lojalista w służbie carskiej; zyskał przecież europejską sławę jako historyk prawa i wydawca źródeł średniowiecznych, słyn-

13 J. Bardach, Wacław Aleksander Maciejowski..., s. 307. Nb. już O. Balzer, odrzucając wiele romantycznych fantasmagorii Maciejowskiego, a opierając się na wytrawnej znajomości źródeł, potrafił naukowo podsumować badania słowianofilskie, formułując zarazem rzetelny program dalszych badań porównawczych, por. O. Balzer, Historia porównawcza praw słowiańskich. Główne kierunki rozwoju nauki i jej istotne zadania, Lwów 1900.

14 Por. W. Kozub-Ciembrowicz, Antoni Zygmunt Helcel (1808-1870), [w:] Złota Ksiega Wydziału Prawa i Administracji UJ, red. J. Stelmach i W. Uruszczak, Kraków 2000, s. 135-144, tamże bogata literatura. Helcel był pierwszym historykiem prawa kierującym w Krakowie katedrą Historii Prawa Polskiego.

15 Por. ogólnie S. Kutrzeba, Historia źródeł dawnego prawa polskiego, I-II, Kraków 1925-1926, dzieło do dziś niestety nieuzupełnione nowymi ustaleniami, nadal niezastąpiony zbiór informacji. 
ny odkrywca m.in. nieznanego tekstu Lex Salica ${ }^{16}$. Polscy historycy prawa byli także niejednokrotnie prekursorami nowoczesnych badań, stosując metody porównawcze, wykorzystując zdobycze etnologii czy socjologii ${ }^{17}$.

Badaczem, który wyszedł z historii prawa, by stać się czołowym polskim historykiem XIX w. był wspomniany już Michał Bobrzyński, profesor Wydziału Prawa UJ w Krakowie. Był w historiografii kontynuatorem tzw. krakowskiej szkoły historycznej (Walerian Kalinka, 1826-1886, był z wykształcenia prawnikiem, główny historyk tej szkoły Józef Szujski, 1835-1883, był historykiem z wykształcenia), która odrzucała zdecydowanie całą romantyczną historiografię, propagując w spojrzeniu na dzieje narodowe po klęsce Powstania Styczniowego spojrzenie realistyczne, często określane pesymistycznym, ale i zarazem w pełni konserwatywne. Bobrzyński to nade wszystko autor głośnej syntezy pt. „Dzieje Polski w zarysie" (I wydanie 1897 r., wielokrotnie wznawiane). Wspomnieć trzeba też jego prace historycznoprawne, wydawnictwa źródłowe, jak i wychowanie znakomitych uczniów jak Bolesława Ulanowskiego, Alfreda Halbana, Stanisława Estreichera, czy nawet wpływ na Oswalda Balzera. Jako autor syntezy kontynuował - w sposób można powiedzieć doskonały - polityczne tradycje Szkoły Krakowskiej $^{18}$. Nie można więc nie podkreślić, iż jedną z zasadniczych do dziś prób spojrzenia na przeszłość narodową sformułował w polskiej historiografii historyk prawa ${ }^{19}$. Bobrzyński zbudował swoją syntezę jako odrzucenie koncepcji

16 Por. W. Sobociński, Wydział Prawa w Uniwersytecie Warszawskim (1816-1831) i Szkole Głównej (1862-1869), [w:] Studia z dziejów Wydziału Prawa Uniwersytetu Warszawskiego, Warszawa 1963, s. 123-143, oraz J. Bardach, Nauka historii państwa i prawa w Królestwie Polskim doby Szkoły Głównej, [w:] idem, Themis a Clio..., s. 253-301, tamże dalsza literatura przedmiotu.

17 Tu wspomnieć trzeba profesora UJ, Lothara Darguna (1853-1893), którego prace znane były w całej Europie, m.in. praca pt. Ursprung und Entwicklungsgeschichte des Eigenthums (1880), Ludwika Gumplowicza (1838-1909), profesora w austriackim Grazu, jednego z twórców socjologii prawa, ale i autora dzieł o dziejach państwa i prawa, a także profesora we Lwowie, Alfreda Halbana (Blumenstocka, 1865-1926), który swoją pozycję międzynarodową na długo utrwalił trzytomowym dziełem pt. Das römische Recht in den germanischen Volksstaaten (1999-1907). Jego uczniem był twórca nowoczesnej polskiej powszechnej historii państwa i prawa, Karol Koranyi (1897-1964), po drugiej wojnie profesor UMK, a następnie UW.

18 Literatura o Szkole Krakowskiej i spory wokół niej miały w dużej mierze charakter sporów politycznych, por. ogólnie W. Łazuga, Michał Bobrzyński. Myśl historyczna a działalność polityczna, Warszawa 1982, oraz K. Grzybowski, Szkoła historyczna krakowska - Michał Bobrzyński (1849-1935), [w:] Studia z dziejów Wydziału Prawa Uniwersytetu Jagiellońskiego, pod red. M. Patkaniowskiego, Kraków 1964, s. 163-186. Warto dodać, iż dość powszechnie się dziś kładzie nacisk na fakt, iż Bobrzyński widział o wiele głębiej obraz dziejów Polski niż Kalinka, czy Szujski, por. M. Jaskólski, Biogram Bobrzyńskiego, [w:] Złota Ksiegga Wydziału Prawa UJ..., s. 179-188.

19 M. Handelsmann, Michał Bobrzyński, [w:] Portrety uczonych polskich, pod red. A. Biernackiego, Kraków 1974, s. 57, pisał o syntezie Michała Bobrzyńskiego: „Będzie się musiało czytać jego dzieło. Gdyż miejsce Bobrzyńskiego jest w jednym szeregu obok Macaulay’a, Micheleta i Taine’a”; por. ogólnie też: W. Kaute, op. cit. Zestawienie literatury przedmiotu i ogólne spojrzenie na jego rolę, por. J. Maternicki, Historia i życie narodu. Pogląy i postawy historyków polskich XIX i XX w., Rzeszów 2009, s. 157-173. 
republikańsko-demokratyzujących Lelewela, kładąc nacisk na to, iż dla narodu, jego bytu, najważniejsze jest istnienie silnego państwa, a nie wolności obywatelskie prowadzące nieraz do anarchii i upadku.

Generacje Michała Bobrzyńskiego czy Alfreda Halbana będą się też tym różnić od romantycznych autorów, iż na czoło w realizacji swej twórczości wysuwać będą jakość warsztatu historycznego, rolę „rzemiosła historycznego”, zgodnie ze wskazaniami ówczesnych najlepszych historyków niemieckich, którzy kontynuowali fachowe wskazania Rankego.

Lista wybitnych historyków prawa końca XIX i początków XX w. jest długa. Wspomniani obok Franciszka Piekosińskiego, kanonistów Bolesława Ulanowskiego i Władysława Abrahama, nade wszystko badacze o najszerszym dorobku naukowym: Oswald Balzer we Lwowie i Stanisław Kutrzeba w Krakowie. Oni także - obok Bobrzyńskiego - winni być zaliczani do „historyków ogólnych”, odgrywali poważną rolę w badaniach ogólnohistorycznych. Bez Ulanowskiego i Abrahama polska mediewistyka, jak i dzieje Kościoła katolickiego w Polsce, pozostawałyby niepełnymi. Znakomity historyk doby po drugiej wojnie światowej, Aleksander Gieysztor, w pełni doceniał dorobek polskiej historiografii prawa zarówno w 1., jak i 2. połowie XIX w. ${ }^{20} \mathrm{O}$ Oswaldzie Balzerze pisał z najwyższym uznaniem $^{21}$. Generalnie Gieysztor podkreślał, iż historycy prawa w Polsce byli pod koniec XIX w. nowatorami, inicjatorami nowych metod badawczych, jak i wiele im zawdzięczała koncepcja historii integralnej, niedalekiej od poglądów F. Braudela, koncepcje historii porównawczej ${ }^{22}$.

Stanisław Kutrzeba, Oswald Balzer, Bolesław Ulanowski czy nieco później Stanisław Estreicher (1869-1939), odgrywali rolę nie tylko swymi dziełami naukowymi, ale i bardzo aktywną rolą w polskim życiu naukowym, zwłaszcza w Polskiej Akademii Umiejętności w Krakowie, początkowo znanej jako Akademia Umiejętności²3. Ich dzieła syntetyczne odgrywały istotną rolę w polskiej historiografii. Stanisława Kutrzeby „Historia ustroju Polski w zarysie”, której tom I popularnie określany jako poświęcony „Koronie”, ukazał się w 1905 r. i odtąd pozostawał podręcznikiem niezrównanym w kraju i za granicą (8 wydań

20 Por. A. Gieysztor, Nauka historyczna na Uniwersytecie Warszawskim, „Rocznik Warszawski” 1992, T. XXII, s. 83-95.

21 A. Gieysztor, Remarques sur l'histoire du droit et les sciences historiques, CPH 1979, t. XXXI, s. 32. "A Lwów, il suffit d'evoquer un tel personnage qu' Oswald Blazer, juriste, au savoir duquel rien n' était étranger et gui dans son métier de recherches historiques s' intéressait même á l' anaiyse philologique et littéraire.... Podkreślał szczególnie Gieysztor, iż historycy prawa myśleli od dawna „strukturalnie”, myśleli kategoriami historii społecznej i gospodarczej.

22 Por. ogólnie uwagi J. Bardach, Aleksander Gieysztor a historia państwa i prawa, [w:] idem, Themis a Clio..., s. 357-382. Gieysztor, warto dodać, iż był uczniem nad wszystko Marcelego Handelsmanna, który swoją wielką karierę historyczną rozpoczynał jako historyk prawa.

23 Por. o S. Kutrzebie: Stanisław Kutrzeba 1876-1946. Materiały z Uroczystego Posiedzenia PAU w dniu 24 czerwca 1996 r., Kraków 1998. 
krajowych, przekłady na niemiecki i rosyjski). Była to w istocie pierwsza nowoczesna próba syntezy dziejów polskich instytucji ustrojowych.

Epoka po odzyskaniu niepodległości w roku 1918 i epoka po drugiej wojnie światowej może wyraziście podzieliła dokonania historyków prawa w Polsce na dwie grupy: coraz wyraźniej rysowała się rola historyków prawa, którzy ograniczali się do badań ściśle historycznoprawnych. Nadal jednak nie brakowało badaczy, którzy odgrywali także wybitną rolę w badaniach ogólnohistorycznych, jak Juliusz Bardach, Adam Vetulani, Bogusław Leśnodorski, czy Stanisław Grodziski.

Kontynuując swe rozważania o roli historyków prawa chciałbym poświęcić parę słów kwestii dość często negliżowanej jaką był fakt, iż szerokie grono polskich historyków, zwłaszcza w Warszawie, w 2. połowie XIX w. i w okresie do roku 1918, było najczęściej z wykształcenia prawnikami. Wynikało to oczywiście z faktu, iż w zaborze rosyjskim nie było swobodnych warunków do studiowania polskiej historii, że Polacy jako humaniści nie mieli wielkich szans na karierę zawodową, którą jednakże - w pewnych granicach - mogło zawsze zapewniać wykształcenie prawnicze umożliwiające kariery adwokata, urzędnika itd. Lista wybitnych uczonych, którzy zazwyczaj byli w tej epoce jedynie prawnikami $\mathrm{z}$ wykształcenia jest długa, oni m.in. stworzyli tzw. warszawską szkołę historyczną w dobie pozytywizmu. Wśród pokolenia najstarszego wspomnieć można Karola B. Hoffmana (1798-1875), prawnika, który jednak obok różnych prac historycznych przeszedł do dziejów historiografii jako krytyk szkoły Lelewelowskiej, w niejednym prekursor szkoły warszawskiej historycznej. Aleksander Kraushar (1843-1931), choć pracował całe życie jako adwokat, był niezwykle płodnym historykiem, znawcą źródeł, ale i odegrał rolę w nauce historii pra$\mathrm{wa}^{24}$. Historykiem prawa i prawnikiem był także Stosław Łaguna (1833-1900), prawnik z zawodu, który jednakże zazwyczaj uważany jest tylko za historyka dziejów społecznych i gospodarczych ${ }^{25}$. Pozytywista Tadeusz Korzon (1839-1918), prawnik z wykształcenia, uważany za czołowego przedstawiciela szko-

24 Był Kraushar autorem rozprawy, ówcześnie ważnej, pierwszych tego typu w Polsce rozważań metodologicznych pt. Uwagi nad historia prawa, Warszawa 1868. Nb. Gustaw Roszkowski, późniejszy profesor prawa międzynarodowego we Lwowie, ogłosił w $1871 \mathrm{r}$. rozprawę pt. Stanowisko szkoły historycznej w nauce prawa, Warszawa 1871, i bronił rozprawy habilitacyjnej (niedrukowanej) o poglądach von Savigny'ego.

25 O liniach rozwojowych polskiej historiografii w okresie do 1918 r., por. generalnie prace A. F. Grabskiego, J. Serczyka i najobszerniejsze opracowanie spraw polskich w monografiach J. Maternickiego, por. idem, Historiografia polska XX w., cz. I: Lata 1900-1918, Wrocław - Łódź 1982, który także na s. 112-129 w pełni docenił fundamentalną wówczas rolę historyków prawa. Wielu przecież wybitnych badaczy do dziś nie posiada opracowań monograficznych, a jedynie zwięzłe biogramy w Słowniku historyków polskich, Warszawa 1994. 
ły warszawskiej historycznej, pozostawił po sobie ogromny dorobek twórczy ${ }^{26}$. Szkoła historyczna warszawska to w pierwszym rzędzie Władysław Smoleński (1851-1926), jeden z najwybitniejszych historyków polskich, prawnik z wykształcenia ${ }^{27}$, Aleksander Rembowski (1847-1906), także prawnik i nade wszystko badacz spraw polskiego ustroju ${ }^{28}$. Zaliczany do tej grupy uczonych Adolf Pawiński (1840-1896) nie był natomiast z wykształcenia prawnikiem, jednakże odegrał główną rolę jako badacz spraw ustrojowych, dziejów społeczeństwa i gospodarki. Był nade wszystko wychowankiem historyków niemieckich (L. Ranke, G. Waitz) ${ }^{29}$. Osobno należy wspomnieć jednego z najwybitniejszych i najbardziej wpływowych polskich historyków okresu sprzed roku 1914, jakim był Szymon Askenazy (1865-1935), prawnik ${ }^{30}$, który jednakże w historiografii odegrał główną rolę jako badacz historii politycznej stając się jednym z ideologów polskiego czynu niepodległościowego ${ }^{31}$. Lista historyków wybitnych u progu XX stulecia, którzy byli także bądź wyłącznie, bądź głównie, z wykształcenia prawnikami, jest długa. Wspomnę tylko

26 Por. ogólnie o przedstawicielach Szkoły Warszawskiej praca zbior. pt. Historycy warszawscy ostatnich dwóch stuleci, Warszawa 1986; a także W. Kamieniecki, Historycy i politycy warszawscy 1900-1950, Wrocław 1992. O T. Korzonie wraz z bibliografią jego prac por. T. Włodarczyk, Tadeusz Korzon. Główne koncepcje historyczne i historiograficzne, Łódź 1958. Wybór jego pism z dziejów wieku XVIII opracowali M. H. Serejski i A. F. Grabski, Odrodzenie w upadku, Warszawa 1975 (seria: Klasycy Historiografii).

27 Por. M. Wierzbicki, Władysław Smoleński, Warszawa 1980, który podkreślił, iż Smoleński studiował prawo „dla chleba”, ale choć nie utrzymywał się z zawodu prawnika, to był nade wszystko pozytywistą z zainteresowań filozoficznych i społecznych, miłośnikiem epoki oświecenia, antyklerykałem o bardzo precyzyjnym sposobie myślenia. Wśród jego najbliższych przyjaciół, stanowiących pewien krąg naukowy, obok także T. Korzona i A. Kraushara byli prawnicy o zainteresowaniach historycznych: Karol Dunin, Adolf Suligowski, Aleksander Rembowski.

28 A. Rembowski był m.in. autorem głośnej rozprawy pt. Konfederacje i rokosze $w$ dawnym prawie państwowym polskim, Warszawa 1893.

29 Jego dzieło do dziś klasyczne, pt. Rządy sejmikowe w Polsce 1572-1795 na tle stosunków województw kujawskich, 1 wydanie 1888 r., wydał ze swoim wstępem H. Olszewski, Warszawa 1978; por. o Pawińskim J. Bardach, [w:] Historycy warszawscy..., Warszawa 1986.

30 J. Maternicki, Historia i życie narodu..., w szkicu o Askenazym napisał, s. 376: „Studia prawnicze wyposażyły S. Askenazego nie tylko w dość szeroką wiedzę politologiczną, ale rozwinęły w nim zdolności logicznego i precyzyjnego myślenia, jak też skłonność do polemiki, podejmowanej często przez historyka.... Postać Askenazego, wielokrotnie, także w Polsce Odrodzonej, zwalczanego przez antysemitów, a w PRL zwalczanego jako przedstawiciela „polskiego nacjonalizmu”, oczekuje ciągle na godną tej postaci wielką monografię.

31 A. Askenazy był m.in. autorem głośnych biografii: księcia Józefa Poniatowskiego (1 wydanie 1905), Łukasińskiego (1908), wielkich dzieł o epoce oświecenia, Napoleona i wieku XIX. Piłsudski, pilny czytelnik dzieł historycznych, przyjmował zarówno romantyzm czynu niepodległościowego z utworów Wyspiańskiego, czy Żeromskiego, jak i z dzieł Askenazego. Równocześnie jednak łączył to z chłodnym realizmem Bobrzyńskiego, zawsze kładąc nacisk na podstawę polityki, jaką musi stanowić budowa silnego państwa. 
krótko kilka ważnych nazwisk: Stanisława Krzyżanowskiego (1865-1917) Adama Szelągowskiego (1873-1961) ${ }^{33}$, Włodzimierza Dzwonkowskiego $(1880-1954)^{34}$, Marcelego Handelsmana $(1882-1945)^{35}$ oraz Władysława Konopczyńskiego (1880-1952) ${ }^{36}$.

Na zakończenie spójrzmy na sytuację historyka prawa w dzisiejszych czasach. Jest rzeczą oczywistą, iż im bardziej współczesne prawo, kształtowane coraz częściej nowoczesnymi metodami unifikacji prawa w skali europejskiej czy międzynarodowej, coraz wyraźniej oddala się od swej regionalnej czy narodowej tożsamości, można mówić o współczesnym prawie stanowionym bez nawiązywania do przeszłości. Nie musi to jednak oznaczać, iż wiedza historycznoprawna, metodologia historycznego spojrzenia na zjawisko prawa, jest dla studenta prawa zbędna czy mało istotna. Nie da się także zaprzeczyć, iż genezy czy punktu

32 Profesor UJ, S. Krzyżanowski, był nade wszystko specjalistą od nauk pomocniczych historii. Wydał m.in. podstawowe do dziś edycje paleograficzne.

33 Adam Szelągowski był uczniem O. Balzera, profesorem historii we Lwowie. Należał do bardzo znanych historyków, ogłaszając dzieła syntetyczne z zakresu historii powszechnej i polskiej. Ważne były jego studia z dziejów polityki zagranicznej Polski, jak i pierwszy zarys polskiej polityki morskiej pt. Sprawa pótnocna w wiekach XVI i XVII, cz. 1-3, 1904-1905.

34 Mistrzem Dzwonkowskiego był Askenazy, z którym wydał „Akty powstania Kościuszki” (1918r.). Był autorem popularnych podręczników historii.

35 M. Handelsman studiował prawo w Warszawie, historię na uniwersytetach niemieckich i w Paryżu. Należał w okresie przed pierwszą wojną światową raczej do historyków prawa, publikując szereg monografii do dziś istotnych, jak Prawo karne w statutach Kazimierza Wielkiego (1909), czy próbę syntezy historii polskiego prawa karnego. Z pozycji wybitnego mediewisty - profesora UW od 1915 r. - przeszedł z czasem głównie do studiów nad epoką napoleońską, działalnością księcia Adama Czartoryskiego i sprawami Wielkiej Emigracji. Napisał wiele znakomitych monografii i był także autorem ważnego w tej epoce podręcznika pt. Historyka. Zasady metodologii i teorii poznania historycznego, $(1921,1928)$. Był niewątpliwie najwybitniejszym historykiem warszawskim dwudziestolecia. W czasie drugiej wojny światowej działał w KG ZWZ-AK, w 1944 r. zadenuncjonowany do gestapo z kół polskiej skrajnej prawicy, por. o nim: A. Gieysztor, Marceli Handelsman, [w:] Portrety uczonych polskich..., s. 199-200, który, przytacza wartą uwagi wypowiedź Handelsmana: „Jedni powiadają, że są specjalistami od historii średniowiecznej, inni od nowożytnej (...). Nie rozumiem tego: albo się jest historykiem, albo się nim nie jest". Podobny pogląd wypowiedział kiedyś Juliusz Bardach. Właśnie historycy prawa wykładający powszechną historię prawa to dydaktycy, którzy muszą ogarniać swoją wiedzą dzieje powszechne od antyku aż po nasze czasy.

36 Tak jak Handelsman był kluczową postacią dla UW w okresie II RP, tak i W. Konopczyński, który poza studiami prawniczymi miał także doktorat na historii u Szymona Askenazego, był nade wszystko profesorem historii UJ, usunięty od dydaktyki dopiero przez władze komunistyczne po drugiej wojnie, Konopczyński należał do najwybitniejszych znawców „Polski nowożytnej” epok zwłaszcza XVII i XVIII w. Jego zasługi jako badacza archiwaliów, autora licznych monografii, prób syntetycznych i biografii są ogromne. Ogłosił m.in. dwutomowe Dzieje Polski nowożytnej (I wyd. 1936), monografię będącą owocem wielu lat poszukiwań archiwalnych o konfederacji barskiej (1936-1938), biografie Stanisława Konarskiego, Kazimierza Pułaskiego, dziesiątki biogramów w PSB, którego był pierwszym znakomitym redaktorem. Swe umiejętności historyczno-prawne wykorzystał nie tylko w dziele o liberum veto, w Chronologii sejmów polskich (1948), ale także wydając edycje źródłowe dla dziejów polskiego parlamentaryzmu, czy pozostawiając w rękopisie niedokończone studia o polskich pisarzach politycznych osiemnastego wieku (częściowo wydane 1966). 
wyjścia prawa współczesnego nie można w pełni odrywać od ewolucji historycznej, od podejścia historycznego, które musi się siłą rzeczy opierać na metodach i wiedzy ogólnohistorycznej jako punktu wyjścia ${ }^{37}$. Stąd nauka historii prawa dawniej i dziś pozostaje specyficzną nauką, która zobowiązana jest posługiwać się metodologią i wiedzą dwóch nauk równocześnie: prawa i historii. Jeżeli głównym przedmiotem zainteresowań historyka prawa są problemy prawa w przeszłości, studiowane w oparciu o terminologię wypracowaną przez nauki prawne i specyficzną metodologię nauk prawnych, to przecież bez równoczesnego stosowania metod nauk historycznych owe badania byłyby bezowocne, niemożliwe. Mamy więc w tej konkretnej sytuacji swego rodzaju sprzężenie zwrotne, konieczność posługiwania się przez historyków prawa całym instrumentarium fachowym historyka. Natomiast historyk, wchodząc w problemy związane ze strukturami i przepisami prawa minionych epok, musi koniecznie sięgać do dorobku historyków prawa ${ }^{38}$. Prawo danej epoki stanowi także, o czym często się zapomina, istotny element historii kultury danej epoki ${ }^{39}$.

Młody historyk prawa, który formalnie nie był równocześnie studentem historii, musi, nolens volens, uzupełniać swe wykształcenie w kierunku przede wszystkim znajomości metodologii nauk historycznych, tzw. nauk pomocniczych historii, w tym szczególnie istotnej nauki o źródłach historycznych ${ }^{40}$. Można oczywiście, jak wielu wybitnych prawników wspomnianych w moim tekście, dochodzić do istotnego quantum wiedzy historycznej własną drogą jednakże uczęszczanie na niektóre wykłady, seminaria historyczne, jak i odbycie praktyki archiwalnej, wydają się absolutnie koniecznym elementem wykształcenia niezbędnego historykowi prawa ${ }^{41}$. Historykowi natomiast, zwłaszcza jeżeli pragnie być mediewistą, specjalistą wewnętrznych dziejów politycznych, spraw gospodarki i stosunków społecznych, to pewne quantum wiedzy z zakresu historii

37 Por. jednak S. Grodziski, Uwagi o historii prawa, jej miejscu wśród innych nauk historycznych i nazwie, „Historyka” 1972, t. III, s. 89-101, oraz M. Wąsowicz, O profesji historyka prawa, „Przegląd Historyczny” 1989, z. 3. s. 19-34, tamże dawniejsza literatura przedmiotu.

38 Jak słusznie wskazuje M. Wąsowicz, op. cit., historyk prawa nie może rezygnować z ogólnej wiedzy o epoce. Jego rozważania są gównie próbą określenia modelu badawczego historyka prawa i zasługiwały na dyskusję, której właściwie nie było.

39 Por. S. Grodziski, Z dziejów staropolskiej kultury prawnej, Kraków 2004.

40 M. Wąsowicz, op. cit., s. 21, porusza problem czy historycy prawa czują się bardziej historykami czy prawnikami, i stwierdza: „W moim przekonaniu historyk prawa, bez względu na to jaką problematyką się zajmuje, jest jednak przede wszystkim historykiem”. Nie można jednak wykluczać podwójnej roli historyków prawa.

41 Historycy prawa nie cieszą się dziś nadmierną estymą wśród przedstawicieli innych nauk prawniczych. Warto jednak zacytować wypowiedź wybitnego specjalisty prawa pracy, Wacława Szuberta (1912-1994), O profesji historyka prawa w tekście pt. Refleksje nie-historyka nad historia prawa, „Państwo i Prawo”, 1994, nr 1, s. 6: „...wszyscy, nie tylko przedstawiciele nauk prawnych, lecz także innych nauk społecznych, jesteśmy - wyrażając się obrazowo - zanurzeni w historii i nawiązujemy do jej dorobku, i staramy się go pomnażać”. 
prawa jest mu niezbędne. Dotyczy to zwłaszcza studentów specjalizujących się w archiwistyce. Absolwent studiów historycznych może bez większych trudności zajmować się na przykład historią ustroju dawnej Rzeczypospolitej, o czym chociażby świadczy przykład świetnej szkoły badań dziejów sejmów i sejmików staropolskich, którą stworzył po drugiej wojnie światowej Władysław Czapliński. Natomiast historyk średniowiecza czy spraw społecznych dawnych epok, a zwłaszcza dziejów przestępczości, historii prawa sądowego, nie może wkraczać $\mathrm{w}$ te dziedziny bez pogłębionej wiedzy historycznoprawnej.

Żyjemy dziś w szkołach wyższych pod presją dydaktyki coraz częściej sterowanej profilem zawodowej kariery widzianej możliwie wąsko, specjalizacyjnie, praktycystycznie ${ }^{42}$. Prawdziwy przecież uniwersytet nie jest i nie może być tylko szkołą zawodową; powinien stwarzać możliwości w miarę swobodnego rozwoju intelektualnego, kształcić także bezinteresownie zainteresowania. Obecna sytuacja, różnorodne limity finansowania dydaktyki, takich możliwości nie stwarzają i to w kraju, który z pewnością jest w sumie zamożniejszy niż był lat temu trzydzieści! Jestem zwolennikiem studiów interdyscyplinarnych, międzywydziałowych, stwarzania więc warunków formalnych dla kształcenia takich, ilościowo siłą rzeczy niewielkich, elit, które mogą w przyszłości określać sukcesy naszej nauki i naszej dydaktyki. Uczelnie państwowe najwyższej rangi nie mogą być jedynie szkołami zawodu, kierowanymi wyłącznie bieżącymi potrzebami rynku pracy, zmiennego jak nigdy wcześniej w dobie globalizacji spraw gospodarki...

Historiografia prawa w Polsce ma wspaniałe, rzadko spotykane tradycje, ale we współczesnej epoce nie można zapomnieć o konieczności stałej współpracy historyków prawa $\mathrm{z}$ wydziałami nauk historycznych. W ostatnich latach, nie tylko w Toruniu, zauważam brak tej współpracy, rozliczne formalistyczne przeszkody wynikające $\mathrm{z}$ faktu, iż każdy wydział uniwersytecki stanowi swego rodzaju zamkniętą całość, a nikt wydaje się już nie pamiętać o zasadzie nowoczesnej nauki: najważniejsze rzeczy w nauce dzieją się nieraz na pograniczu różnych nauk, niekiedy dość od siebie dalekich, jak na przykład fizyka, medycyna i biologia, czy chemia i paleontologia...

42 Także K. Sójka-Zielińska, Nauczanie historii prawa w czasach przemian ustrojowych, [w:] Humanizacja zawodów prawniczych a nauczanie akademickie, red. A. Turska, Warszawa 2002, s. 39-49, położyła nacisk na rolę studium historii prawa dla prawnika i przypomniała słowa pierwszego dziekana na Wydziale Prawa UW., Jana Wincentego Bandtkie, który pisał: „Nauka prawa - bez historii prawa w żaden sposób obejść się nie może, od niej początek brać, na niej gruntować się powinna. Ona nadała nauce prawa światła i godności tych, których teraz zażywa" (op. cit., s. 44). 